\title{
ASUHAN KEBIDANAN CONTINUITY OF CARE DI KLINIK MEDIKA UTAMA SIDOARJO
}

\author{
Felia Julianti Fitri", Setiawandari*** \\ *Prodi DIII Kebidanan Universitas PGRI Adi Buana Surabaya \\ *** Prodi Profesi Kebidanan Universitas PGRI Adi Buana Surabaya \\ setiawandari@unipasby.ac.id
}

\begin{abstract}
ABSTRAK
Continuity of Care merupakan program peningkatan pemberian pelayanan kebidanan secara kontinyu yang dilaksanakan oleh Bidan dan sebagai tugas akhir mahasiswa kebidanan dengan mengedepankan asuhan kebidanan secara holistik dan terpadu. Tujuan dari penelitian ini adalah memberikan asuhan kebidanan secara berkesinambungan pada Ny.N 36 tahun multipara di Klinik Medika Utama Sidoarjo. Desain penelitian adalah diskriptif dengan jenis penelitian studi kasus. Hasil penelitian menunjukkan asuhan kebidanan yang diberikan pada $\mathrm{Ny} . \mathrm{N}$ mulai dari kehamilan, persalinan, nifas, bayi baru lahir, dan keluarga berencana berjalan sesuai dengan standar asuhan kebidanan. Simpulan setelah diberikan asuhan kebidanan Continuity of Care ibu merasa nyaman, komplikasi yang terjadi dapat teratasi dan terdeteksi sejak awal kehamilan, ibu dan bayi mendapatkan asuhan yang adikuat dan terintegrasi.
\end{abstract}

Kata kunci : Asuhan Kebidanan, Continuity of Care

\begin{abstract}
Continuity of Care is a program to improve the provision of midwifery services continuously carried out by Midwives and as the final project for midwifery students by promoting holistic and integrated midwifery care. The aim of this study was to provide continuous midwifery care for the multiparous mother, 36 year old, Mrs. N at the Medika Utama Clinic, Sidoarjo. The research design is descriptive with the case type of study research. The results showed that the midwifery care provided to Mrs. N, starting from pregnancy, childbirth, postpartum, newborns, and family planning, went according to midwifery care standards. Conclusions after being given Continuity of Care midwifery care, the mother feels comfortable, the occurring complications can be resolved and detected since the beginning of pregnancy, the mother and baby received adequate and integrated care.
\end{abstract}

Keyword: Midwifery Care, Continuity of Care

\section{PENDAHULUAN}

Pemerintah dalam usahanya meningkatkan Kesehatan ibu dan anak serta menurunkan angka kematian ibu dan bayi di

Indonesia telah melakukan kebijaksaankebijaksanaan kesehatan diantaranya safemotherhood, Making Pregnancy Safer 
(MPS), Program Perencanaan Persalinan dan Pencegahan Komplikasi (P4K), Jamkesda, Jampersal, Millennium Developmens Goals (MDGs). Tetapi beberapa kebijakan tersebut belum bisa menjawab semua kebutuhan kesehatan ibu dan anak.

Oleh karena itu untuk melanjutkan program pemerintah berkaitan dengan usaha meningkatkan kesehatan ibu dan anak, maka Bidan diharuskan memberikan pelayanan kebidanan secara berkesinambungan (Continuity of Care) mulai dari antenatalcare, intranatalcare, bayi baru lahir dan neonatal, potsnatalcare, sampai keluarga berencana yang berkualitas. Seorang bidan diharapkan melakukan praktik kebidanan dengan pendekatan fisiologis, menerapkan dan mengembangkan model praktik bidan berdasarkan Evidence Based Practice. Hal ini berdasarkan rekomendasi WHO bahwa asuhan kebidanan model CoC meliputi kesinambungan perawatan, memantau kesejahteraan fisik, psikologis spiritual dan sosial wanita dan keluarga selama siklus melahirkan, memberikan wanita pendidikan, konseling dan ANC individual, kehadiran selama persalinan, kelahiran dan periode pascapartum langsung oleh bidan yang dikenal, dukungan berkelanjutan selama periode paska melahirkan, meminimalkan intervensi teknologi yang tidak perlu, dan mengidentifikasi, merujuk dan mengkoordinasikan perawatan untuk wanita yang membutuhkan perhatian kebidanan atau spesialis lainnya (1). Tujuan utama Continuity of Care dalam asuhan kebidanan adalah salah satunya mengubah paradigma bahwa hamil dan melahirkan bukan suatu penyakit, melainkan sesuatu yang fisiologis dan tidak memerlukan suatu intervensi. Keberhasilan CoC akan meminimalisir intervensi yang tidak dibutuhkan dan menurunkan kasus keterlambatan penatalaksanaan kegawatdaruratan maternal neonatal.
Continuity of Care kini telah terintegrasi dalam pendidikan kebidanan memberikan banyak manfaat kepada mahasiswa kebidanan dalam pemahamannya untuk merawat wanita secara menyeluruh dan terintegrasi. Bidan dan mahasiswa bidan mendapatkan kesempatan dapat mengeksplorasi asuhan yang diberikan mulai dari kehamilan sampai dengan paska melahirkan berdasarkan Evidence Based Practice. Bagi pastisipan atau ibu hamil yang mendapatkan pendampingan, merasa puas dengan asuhan $\mathrm{CoC}$ yang diberikan, ibu merasa aman dan nyaman karena mendapatkan pemantauan kesehatan yang berkesinambungan dengan pendekatan yang humanis (2). Selain itu bukti penelitian lainnya melaporkan bahwa hampir semua perempuan menyambut baik kesempatan untuk membangun hubungan yang suportif, autentik, menghargai konsistensi, tidak tergesa-gesa dan berpusat pada wanita (1).

\section{BAHAN DAN METODE}

Penelitian ini menggunakan metode diskriptip dengan pendekatan studi kasus. Dilakukan di Klinik Medika Utama Sidoarjo mulai tanggal 1 April 2020 sampai dengan 28 Mei 2020. Sampel penelitian yaitu Ny.N Multipara Usia Kehamilan 37 minggu.

\section{HASIL PENELITIAN}

a. Setelah dilakukan Contuinity of Care pada Ny.N mulai dari asuhan kehamilan, asuhan persalinan, asuhan bayi baru dan neonatal, asuhan nifas, sampai dengan ibu mengikuti program KB, semua berjalan sesuai dengan harapan, ibu dan bayi sehat dan selamat, komplikasi dapat teratasi.

b.Asuhan kebidanan kehamilan pada Ny.N umur 36 tahun dilakukan sebanyak 13 kali kunjungan. Pada penapisan faktor resiko dengan KSPR, didapatkan skor 10, 
sehingga ibu dikatagorikan kehamilan dengan faktor resiko sedang. Skor 10 diperoleh dari, usia ibu > 35 tahun, pernah abortus, dan skor awal kehamilan. Dengan keteraturan kunjungan antenatal care yang dilakukan oleh ibu di Klinik Medika Utama, kehamilan Ny.N berjalan tanpa komplikasi dan terintegrasi.

c.Asuhan kebidanan persalinan Ny.N, ibu melahirkan pada tanggal 16 April 2020 jam 08.30. Proses persalinan kala I berlangsung 7 jam, kala II berlangsung 1 jam 45 menit dan lama kala III 40 menit. Terjadi komplikasi pada kala III, dimana ibu mengalami retensio plasenta. Dengan penatalaksanaan yang adikuat dan sesuai dengan prosedur, komplikasi bisa diatasi sehingga proses persalinan Ny.N berlangsung dengan lancar dan aman. Kala IV 2 jam postpartum keadaan ibu stabil, tidak teridentifikasi adanya perdarahan.

d.Asuhan kebidanan nifas Ny.N, dilakukan kunjungan sebanyak 2 kali dan 1 kali secara virtual. Selama kunjungan nifas, keluhan ibu tentang kurangnya produksi ASI ibu diawal masa nifas telah mendapatkan asuhan kebidanan komplementer pijat oksitosin. Sehingga pada kunjungan yang kedua pada tanggal 20 April 2020, ibu menyampaikan bahwa produksi ASI nya telah meningkat. Selain itu ibu juga merasakan nyeri perinium pada hari pertama pasca melahirkan dan dapat teratasi dengan teknik relaksasi dan distraksi. Bidan memberikan konseling tentang pentingnya menjaga kebersihan perinium dan mengkonsumsi makanan tinggi kalori dan tinggi protein. Diet TKTP juga bermanfaat untuk memperbanyak produksi ASI serta mempercepat pemulihan kesehatan ibu pasca persalinan. e. Asuhan kebidanan bayi baru lahir Ny.N, dilakukan kunjungan sebanyak 2 kali dan 1 kali secara virtual. Bayi lahir tanggal 16 April 2020, jam 10.15 WIB. APGAR skor 8-9 BBL 3300 gram PB $50 \mathrm{~cm}$. Asuhan yang diberikan pada bayi baru lahir sampai dengan neonatal telah sesuai dengan standar pelayanan. Bayi mendapatkan cukup nutrisi yaitu ASI saja, sehingga tidak mengalami penurunan berat badan melebihi normal. Bayi juga tidak mengalami ikterus neonatorum. Tandatanda vital dalam batas normal, eliminasi lancar, dan bayi menyusu kuat.

f. Asuhan kebidanan keluarga berencana, dilakukan 1 kali bersamaan dengan asuhan masa nifas ke tiga secara virtual pada tanggal 14 Mei 2020 dan 1 kali pada 40 hari postpartum di Klinik Medika Utama Sidoarjo. Pada kunjungan KB pertama, Bidan dan mahasiswa bidan memberikan konseling tentang manfaat keluarga berencana, jenis alat kontrasepsi, cara kerja, dan efek samping dengan menggunakan bahasa yang mudah dipahami oleh ibu, sehingga pada 40 hari postpartum Ibu dan keluarga sudah memutuskan menjadi akseptor KB. Pada tanggal 25 Mei 2020 Ny.N telah menggunakan metode kontrasepsi injeksi 3 bulan.

\section{PEMBAHASAN}

Pelaksanakan asuhan kebidanan pada Ny.N 36 tahun multipara dimulai sejak tanggal 1April 2020 sampai dengan 28 Mei 2020. Adapun asuhan yang telah dilakukan adalah asuhan kehamilan pada trimester III, persalinan, penatalaksanaan bayi baru lahir sampai dengan neonatus, nifas dan keluarga berencana. Asuhan kebidanan di tengah kondisi pandemi Covid-19 dilakukan dengan cara pendampingan dan secara daring dengan menerapkan protokol kesehatan. Pada artikel 
ini, penulis hanya menuliskan kesenjangan yang di temukan selama pengkajian data, pelaksanaan asuhan dan evaluasi. Ny. $\mathrm{N}$ juga telah melakukan protokol kesehatan tatalaksana persalinan di masa pandemi dengan melaksanakan rapid tes serologi covid 19 dengan hasil non reaktif.

\section{a. Continuity of Care (CoC)}

Hal yang menjadi dasar dalam model praktik kebidanan adalah memberikan asuhan yang menyeluruh, dengan membangun kemitraan yang terintegrasi dan berkelanjutan guna saling memberikan dukungan dan membangun hubungan saling percaya antara Bidan dengan ibu (2). Continuity of Care merupakan praktik kebidanan yang berkesinambungan dan holistik mulai dari antenatal, intranatal, postnatal, neonatus sampai keluarga berencana, yang menghubungkan antara kebutuhan kesehatan wanita dengan keadaan pribadi setiap individu (3). Sedangkan menurut Mclachlan, Continuity of Care adalah asuhan yang menitikberatkan pada suatu keadaan yang alamiah yaitu membantu wanita untuk dapat melahirkan dengan intrusi atau campur tangan minimal dengan tetap mendapatkan pemantauan keadaan fisik, kesehatan psikologis, spiritual dan sosial ibu dan keluarga (4).

Hasil penelitian melaporkan, perempuan merasakan kepuasan yang lebih tinggi atas pendampingan yang diberikan oleh Bidan. Rasa puas ibu dikaitkan dengan pemberian saran, informasi, konseling, tempat melahirkan, persiapan melahirkan, metode untuk mengurangi nyeri persalinan dan pemantauan secara insentif oleh bidan. Sehingga ibu merasa bahwa bidan adalah "temannya". Menurut Forster et al (2016) $\mathrm{CoC}$ adalah rancangan pembelajaran berbasis pasien dengan klien sebagai bahan ajar, sehingga mampu meningkatkan pengetahuan mahasiswa bidan terhadap filosofi asuhan kebidanan secara menyeluruh dan terintegrasi (5).

b. Asuhan kehamilan

Asuhan kebidanan pada Ny.N 36 tahun $\mathrm{G}_{2} \mathrm{P}_{0010}$ di Klinik Medika Utama Sidoarjo telah dilakukan penulis sebanyak 3 kali dengan 2 kali melalui pendampingan dan 1 kali melalui daring. Hasil pengkajian data didapatkan, bahwa Ny.N telah melakukan kunjungan kehamilan sebanyak 13 kali, dimulai usia kehamilan 8 minggu. Asuhan yang diberikan kepada ibu telah sesuai dengan standar 10T asuhan kebidanan yang ditetapkan oleh Kemenkes RI (2009) yaitu: timbang berat badan dan ukur tinggi badan, pemeriksaan tekanan darah, tinggi fundus uteri, skrining status imunisasi, pemberian tablet tambah darah, menentukan status gizi, tes laboratorium, menentukan presentasi janin dan DJJ, tatalaksana kasus dan temu wicara.

Hasil penghitungan KSPR Ny.N pada awal kunjungan adalah 10 skor. Penjumlahan didapatkan dari skor awal kehamilan 2, usia ibu lebih dari 35 tahun $=$ 4 dan ibu mempunyai riwayat kegagalan pada kehamilan pertamanya $=4$. Salah satu standar pelayanan antenatal care adalah pengisian KSPR secara lengkap, agar deteksi resiko tinggi kehamilan dapat diketahui sejak dini (6). Jumlah kunjungan yang intens ini dilakukan Ny.N sehubungan dengan ibu mempunyai riwayat abortus, sehingga ibu merasa harus lebih hati-hati dalam menjaga kehamilan selanjutnya. Dan ibu telah memilih tempat pemeriksaan kehamilan di Klinik, dimana walaupun ibu hamil dengan resiko tinggi tetapi ibu masih bisa persalinan dengan bidan dibawah pengawasan dokter spesialis kandungan.

Pada pemeriksaan abdomen Ny.N usia kehamilan 36-37 minggu tinggi fundus uteri $32 \mathrm{~cm}$. Pada usia kehamilan 38 minggu tinggi fundus uteri $31 \mathrm{~cm}$ dan usia kehamilan 39 minggu tinggi fundus uteri 30 
cm. Adanya kesenjangan antara usia kehamilan dengan tinggi fundus uteri dimana menurut teori Spiegelberg, bahwa pada usia kehamilan 36-37 minggu tinggi fundus uteri $32 \mathrm{~cm}$, usia kehamilan 38 minggu tinggi fundus uteri setinggi $33 \mathrm{~cm}$, dan usia kehamilan 39-40 minggu tinggi fundus uteri $37,7 \mathrm{~cm}$ (Muchtar, R. 2014). Pengkajian usia kehamilan dengan tinggi fundus uteri digunakan sebagai indikator pemantauan pertumbuhan janin, dengan menggunakan metode Jhonson dapat memperkirakan taksiran berat badan janin. Mengkaji ukuran uterus secara klinis untuk membandingkannya dengan usia kehamilan tidak selalu memberikan hasil yang akurat, hal ini dikarenakan ukuran dan jumlah janin serta jumlah cairan amnion yang bervariasi atau adanya kesalahan pengukuruan.

Berdasarkan penghitungan Indek Masa Tubuh (IMT), Ny.N termasuk dalam katagori normal, sehingga kenaikan berat badan yang diharapkan selama kehamilan adalah 11,5-16 kg. Pada Ny.N, ketidak sesuaian antara usia kehamilan dengan tinggi fundus uteri ini kemungkinan dikarenakan adanya hubungan kenaikan berat badan ibu selama kehamilan yang hanya naik $7 \mathrm{~kg}$. Beberapa faktor yang mempengaruhi kenaikan berat badan ibu hamil diantaranya asupan nutrisi, aktivitas ibu dan status antropometri ibu di awal kehamilan (7). Selain hal tersebut faktor alat pengukur berat badan juga harus diperhatikan, sehingga untuk mencegah ketidaksesuaian maka alat-alat kesehatan salah satunya timbang badan perlu dilakukan kalibrasi secara kontinyu.

Pemeriksaan tes laboratorium pertama Ny.N dilaksanakan pada tanggal 31 Oktober 2019, didapatkan hasil HB 10,3 gr\% sehingga ibu dikatagorikan kehamilan dengan anemia ringan. Hasil tes laboratorium kedua pada tanggal 23 Maret $2020 \mathrm{HB}$ ibu telah mencapai normal yaitu
12,8 gr \%. Standar tes laboratorium dalam kehamilan dilakukan minimal sebanyak dua kali yaitu pada usia kehamilan trimester kesatu dan trimester ketiga, hal ini bertujuan agar bisa segera ditindaklanjuti jika ibu menderita anemia. Menurut Bobak (2014) ibu dikatakan anemia jika kadar HB pada trimester I <11 gr/dl, trimester II $<10,5 \mathrm{gr} / \mathrm{dl}$ dan trimester III $<10 \mathrm{gr} / \mathrm{dl}$. Anemia pada kehamilan beresiko terjadi komplikasi kehamilan diantaranya hyperemesis gravidarum, kegagalan kehamilan, bayi lahir premature, ketuban pecah dini, daya tahan tubuh ibu lemah sehingga mudah mengalami infeksi, dan proses pemulihan masa nifas lama (8). Tatalaksana yang telah didapatkan oleh ibu adalah pemberian tablet tambah darah ferro sulfat $60 \mathrm{mg} /$ hari dengan tatacara minum yang benar. Selain itu ibu juga mendapatkan konseling untuk mengkonsumsi makanan rumahan dengan bahan dasar kandungan zat besi tinggi didalamnya seperti daun bayam, daun kelor, daun katuk, hati ayam, dan lain-lain dengan harga yang terjangkau. Dengan penatalaksanaan yang adikuat oleh Bidan, kadar HB ibu pada trimester III telah mencapai normal.

\section{c. Asuhan persalinan}

Asuhan persalinan pada Ny.N pada tanggal 16 April 2020 di Klinik Medika Utama Sidoarjo, diperoleh data yaitu Ny.N melahirkan spontan belakang kepala pada tanggal 16 April 2020 jam 10.15 WIB, dengan total lama kala satu 7 jam, lama kala dua 1 jam 45 menit, lama kala tiga 40 menit dan kala empat 2 jam.

Kala I Ny.N dimulai pada pukul 01.30 dengan pembukaan serviks $2 \mathrm{~cm}$ sampai dengan pukul 08.30. Menurut Friedman, lama persalinan kala I pada ibu primipara adalah $\pm 13,3$ jam, sedangkan pada multipara $\pm 7,5$ jam (Betsy B Kennedy, 2014). Kehamilan Ny.N adalah kehamilan 
yang kedua, tetapi pada kehamilan pertama ibu mengalami Abortus. Sehingga proses persalinan kala II ibu, didahului dengan pembukaan pada ostium uteri internum (OUI) yaitu pendataran dan penipisan serviks kemudian baru pembukaan ostium uteri eksternal.

Kesesuaian waktu proses persalinan kala I dihasilkan dari perkembangan his Ny.N yang adikuat, ibu aktif mobilisasi dan pengosongan kandung kemih yang intens, ibu juga melaksanakan nasihat bidan untuk makan dan minum sesuai kebutuhan serta melakukan stimulasi putting susu. Penatalaksanaan yang diberikan Bidan untuk mengatasi nyeri persalinan adalah dengan teknik relaksasi nafas dalam (Deep Breathing Relaxation Techniques). Tehnik relaksasi nafas dalam merupakan asuhan nyeri persalinan yang paling sering digunakan dengan menggunakan pendekatan perilaku kognitif. Hasil penelitian tentang tehnik relaksasi nafas dalam pada 492 persalinan di PMB Wilayah Kerja Puskesmas Raja Basa Indah Kota Bandar Lampung melaporkan $\mathrm{p}=0,000$ sehingga disimpulkan ada pengaruh tehnik nafas dalam terhadap penurunan nyeri persalinan kala I (9).

Kala II Ny.N berlangsung hampir 2 jam, dimulai dari pukul 08.30 sampai dengan pukul 10.15 WIB. Menurut Saifuddin (2014) kala II dimulai dari pembukaan lengkap $(10 \mathrm{~cm})$ sampai bayi lahir, pada primipara berlangsung 2 jam, dan pada multipara berlangsung 1 jam. Ny.N melahirkan spontan belakang kepala dengan jenis kelamin laki-laki, APGAR scor 9-10 pada tanggal 16 April 2020 jam 10.15 WIB. Sebelum bayi lahir, bidan melakukan tindakan episiotomy dengan indikasi perinium kaku. Tindakan episiotomi dalam persalinan tidak dianjurkan dilakukan secara rutin, melainkan jika ada indikasi tertentu seperti bayi besar, foetal distress, perinium kaku atau persalinan dengan tindakan. Hal ini dikarenakan akan menyebabkan ketidaknyamanan pada ibu pasca melahirkan. Sejalan dengan hasil penelitian Nuring Pangastuti (2016) tentang robekan perinium, dengan subyek penelitian sebesar 1595 ibu melahirkan, melaporkan bahwa robekan perinium terjadi pada $80,55 \%$ usia muda, 69,14\% usia lebih dari 35 tahun, $85,05 \%$ pada primipara. Korelasi positif $(0,027)$ menunjukkan bahwa berat bayi lahir makin besar, resiko robekan perinium meningkat. Lama kala II juga berhubungan dengan robekan perinium $(\mathrm{p}=0,018)$ untuk lama kala II 30-60 menit, dan $\mathrm{p}=0,002$ untuk lama kala II lebih dari 60 menit (7). Berdasarkan dengan penelitian tersebut, selain faktor perinium kaku, usia ibu yang lebih dari 35 tahun kemungkinan juga bisa menjadi penyebab lamanya kala II.

Kala III persalinan Ny.N berlangsung 40 menit, dimulai dari pukul 10.15 WIB sampai dengan pukul 10.55 WIB. Pada asuhan persalinan kala tiga ditemukan komplikasi persalinan yaitu retensi plasenta. Menurut Saifudin (2009) jika plasenta tertahan dalam cavum uteri sampai dengan 30 menit setelah kelahiran bayi, maka ibu mengalami retensio plasenta. Faktor penyebab retensio plasenta adalah usia, paritas dan anemia (Oxorn, 2010). Pada ibu dengan usia kurang dari 20 tahun, organ reproduksinya belum berkembang secara sempurna sedangkan ibu hamil dengan usia lebih dari 35 tahun organ reproduksi mengalami penurunan fungsi dan penurunan desidua secara progresif sehingga mengganggu tempat implantasi plasenta (Wiknjosastro, 2007; Oxorn, 2012). Sejalan dengan penelitian Riyanto (2015) terhadap 843 persalinan di RSUD Dr.H.Bob Bazar Kalianda tahun 2011-2013 melaporkan bahwa faktor-faktor yang paling bermakna terhadap kejadian retensio 
plasenta adalah umur ibu $(\mathrm{p}=0,040)$ dan anemia $(0,027) \cdot{ }^{9}(10)$.

Penatalaksanaan yang telah dilakukan bidan adalah stimulasi putting susu, injeksi oksitosin ke dua (10 unit), dan pengosongan kandung kemih. Tetapi setelah 30 menit kemudian plasenta tidak segera lepas, walaupun telah ada perdarahan minimal. Sebelum Bidan melakukan tindakan manual plasenta, ibu terlebih dahulu dipasang infus RL $500 \mathrm{ml}$ 20 tetes/menit sebagai tindakan antisipasi perdarahan hebat pasca manual plasenta. Asuhan yang diberikan oleh bidan telah sesuai dengan teori penatalaksanaan komplikasi persalinan dengan retensio plasenta. Pada pukul 11.03 WIB plasenta lahir manual, perdarahan $\pm 100 \mathrm{cc}$ dan kontraksi fundus teraba keras.

Kala IV persalinan Ny.N dimulai pukul 11.05 WIB sampai dengan 13.05 WIB. Hasil observasi 2 jam postpartum, tandatanda vital dalam batas normal, tinggi fundus uteri 1 jari dibawah umbilikal, kontraksi uterus keras, kandung keming kosong dan jumlah perdarahan $\pm 150 \mathrm{cc}$. Penatalaksanaan tindakan pada persalinan dengan retensio plasenta telah dilaksanakan sesuai dengan prosedur, sehingga tidak ditemukannya hasil yang menyimpang pasca tindakan manual plasenta. Rehidrasi Infus RL $500 \mathrm{ml}$ drip oksitosin 10 unit dilanjutkan sampai dengan 6 jam postpartum.

d. Asuhan nifas

Asuhan nifas pada Ny.N dilaksanakan dengan pendampingan dan daring. Pada kunjungan nifas pertama (KF1) dilaksanakan pada 6 jam postpartum dan kunjungan nifas kedua (KF2) yaitu 7 hari postpartum dilakukan di klinik, sedangkan kunjungan nifas ketiga (KF3) dilakukan secara virtual pada 29 hari postpartum. Selama asuhan, didapatkan data obyektif tekanan darah dan tanda-tanda vital lainnya dalam batas normal. Keluhan ibu adalah masih sedikitnya produksi ASI, Bidan memberikan asuhan pijat oksitosin untuk memperlancar produksi ASI ibu. Stimulasi pijat oksitosin dilakukan sepanjang tulang belakang sampai costa kelima-keenam akan menstimulasi hipofise posterior memproduksi hormon oksitosin. Hipotalamus memproduksi hormon oksitosin yang kemudian lewat aksoplasmed dibawa ke hipofise posterior. Hormon oksitosin akan dilepas kedalam darah jika ada stimulasi pada hipofise posterior. Konseling lainnya adalah memotivasi ibu untuk sering melakukan perawatan payudara sederhana secara rutin dan mengkonsumsi bahan makanan yang dapat merangsang produksi ASI seperti daun kelor atau daun katuk. Ibu juga disarankan untuk istirahat cukup dan tidak stress.

Luka episiotomi tingkat II membuat ibu merasakan nyeri perinium, tindakan episiotomi dilakukan bidan dengan indikasi perinium kaku dan lama kala II yang hampir dua jam. Menurut Nuring Pangastuti (2016) melaporkan adanya hubungan antara lama kala II 30-60 menit dengan robekan perinium $(\mathrm{p}=0,018)$, sehingga jika lama kala II semakin memanjang maka kejadian robekan perinium akan meningkat (7). Untuk menghindari derajat robekan lebih luas dan mencegah komplikasi Kala II lama bidan melakukan episiotomi. Tindakan episiotomi dilakukan kepada ibu melahirkan dengan tetap memperhatikan prosedur sayang ibu. Untuk mengurangi nyeri Bidan memberikan asuhan relaksasi dan distraksi.

\section{e. Asuhan bayi baru lahir (neonatus)}

Pada tanggal 16 April 2020 jam 16.15 WIB dilaksanakan asuhan neonatus yang pertama (KN1). Hasil pengkajian bayi lahir spontan belakang kepala, laki-laki, 
APGAR score 8-9, pada penilaian awal kelahiran bayi menangis kuat, kulit kemerahan dan tonus otot aktif. BBL 3300 gram PB $51 \mathrm{~cm}$, lingkar kepala $34 \mathrm{~cm}$ dan lingkar dada $35 \mathrm{~cm}$. Terdapat lubang anus, testis sudah turun, reflek primitive normal. Kesenjangan yang ditemukan adalah adanya perbedaan antara ukuran tinggi fundus uteri, kenaikan berat badan ibu selama kehamilan dengan berat badan lahir. Hal ini tidak sesuai dengan hasil penelitian melaporkan bahwa adanya hubungan Indeks Masa Tubuh (IMT) pra hamil dengan berat badan bayi lahir $(\mathrm{p}=0,006)$ dan kenaikan berat badan ibu selama hamil dengan berat badan bayi lahir $(\mathrm{p}=0,024){ }^{10}$ (11). Oleh karena itu perlu adanya kolaborasi pemeriksaan ultrasonografi untuk membantu menegakkan diagnosis tentang pertumbuhan janin didalam intra uteri sebagai deteksi dini adanya komplikasi seperti pertumbuhan janin terhambat (intrauterine growth retardation) dan intra uterin fetal death.

Penatalaksanaan asuhan bayi baru lahir seperti IMD, pemberian salf mata erythromycin $1 \%$, injeksi vitamin $\mathrm{K} 0,5 \mathrm{ml}$ (i.m) dan imunisasi HB unijek 0,5 ml (i.m), sudah sesuai dengan standar operasional prosedur perawatan bayi baru lahir. Kunjungan kedua (KN 2) usia 7 hari dan kunjungan ketiga (KN3) dengan virtual pada usia 29 hari, diperoleh data bayi menyusu kuat, tidak didapatkan ikterus neonatorum, berat badan naik 6 ons, tali pusat lepas pada hari ke 10, eliminasi lancar.

\section{f. Asuhan keluarga berencana}

Asuhan keluarga berencana dilakukan satu kali virtual bersamaan dengan kunjungan nifas ketiga, dan satu kali kunjungan ke klinik. Pada kunjungan kedua 40 hari postpartum pada tangal 25 Mei 2020, setelah ibu mendapatkan konseling metode kontrasepsi dan pemeriksaan fisik tidak ada kontra indikasi, ibu dan suami memilih metode kontrasepsi injeksi 3 bulan. Metode kontrasepsi injeksi DMPA (Depot medroksiprogesteron asetat) berisi hormone progesterone dengan dosis 150 $\mathrm{mg} / \mathrm{ml}$ merupakan kontrasepsi efektif pada ibu menyusui, dikarenakan tidak mempengaruhi produksi ASI, walaupun mempunyai keterbatasan sering ditemukannya gangguan haid pada akseptor (12). Hasil penelitian Eline Charla S. Bingan tentang pemakaian KB Suntik 3 bulan dengan kecukupan ASI Ekslusif pada ibu yang menyusui anak usia 7-23 bulan, dengan jumlah sampel ibu menyusui sebanyak 39 orang, diperoleh hasil 80,6\% $(\mathrm{p}=0,039) \quad$ mengalami ASI cukup. Kesimpulan dari penelitian diatas adalah adanya hubungan antara pemakaian KB suntik 3 bulan dengan ASI eksklusif (13). Alat kontrasepsi yang mengandung estrogen atau estradino sipionat dapat mengurangi produksi ASI, sehingga tidak disarankan bagi ibu menyusui.

Hormon estrogen yang terdapat pada alat kontrasepsi menyebabkan penekanan pada FSH, sehingga merangsang lobus anterior hipofise memproduksi luteinising hormone. Hormon ini menyebabkan hipotalamus melepaskan faktor penghambat prolaktin, yaitu dopamine. Dopamin menurunkan sekresi prolaktin sehingga sel-sel alveoli tidak memproduksi air susu. Ibu bersedia kontrol ulang KB pada tanggal 18 Agustus 2020, atau jika sewaktu-waktu mempunyai keluhan.

\section{SIMPULAN DAN SARAN \\ Simpulan}

Pelaksanaan asuhan kebidanan secara Continuity of Care pada Ny.N berjalan dengan lancar. Ibu dan bayi dalam keadaan sehat dan normal. 
a. Asuhan kebidanan kehamilan ditemukan KSPR ibu 10. Dengan asuhan kehamilan adikuat dan terintregrasi, keluhan ibu selama kehamilan dan keadaan anemia ringan dapat diatasi. Ny.N mendapatkan program pelayanan atau asuhan standar minimal 10T

b. Asuhan kebidanan persalinan berlangsung normal, tetapi 60 langkah APN tidak dilakukan dikarenakan ditemukan komplikasi retensio plasenta pada kala III persalinan. Dengan penatalaksanaan yang adikuat dan kolaborasi dengan dokter, ibu tidak mengalami perdarahan.

c. Asuhan kebidanan nifas, keluhan produksi ASI sedikit, dapat diatasi dengan asuhan kebidanan komplementer pijat oksitosin. Nyeri perinium berkurang dengan teknik relaksasi dan distraksi.

d. Asuhan kebidanan bayi baru lahir, bayi mendapatkan cukup asupan gizi dari ASI ibu sehingga berat badan bayi naik dan tidak mengalami ikterus neonatorum.

e. Asuhan kebidanan keluarga berencana, ibu menggunakan metode kontrasepsi injeksi tiga bulan dan tidak mengalami efek samping.

\section{Saran}

Asuhan kebidanan Continuity of Care merupakan asuhan yang komprehensif dan terbukti efektif menurunkan Angka Kematian Ibu dan Bayi. Asuhan pada ibu mulai dari kehamilan sampai dengan keluarga berencana harus dilaksanakan secara adikuat, berkesinambungan dan terintegrasi, dilaksanakan mulai dari tingkat pelayanan kesehatan dasar sampai dengan rumah sakit. Mahasiswa Bidan, Bidan dan tenaga medis serta tenaga paramedis lainnya harus mempunyai komitmen bersama dalam usaha meningkatkan kesehatan ibu dan anak.

\section{DAFTAR PUSTAKA}

1. WHO. WHO recommendation on midwife-led continuity of care during pregnancy. WHO Reprod Heal Libr [Internet]. 2016;(November):1-6. Available from:

https://extranet.who.int/rhl/topics/imp roving-health-systemperformance/implementationstrategies/who-recommendationmidwife-led-continuity-care-duringpregnancy

2. Yani LY, Yanti AD. Pelaksanaan "Continuity of Care" Oleh Mahasiswa Kebidanan Tingkat Akhir. Conf Res Community Serv | ISSN 2686-1259. 2016;955-60.

3. Homer CSE, Besley K, Bell J, Davis D, Adams J, Porteous A, et al. Does continuity of care impact decision making in the next birth after a caesarean section (VBAC)? A randomised controlled trial. BMC Pregnancy Childbirth. 2013;13(page $14): 2-6$.

4. McLachlan HL, Forster DA, Davey MA, Farrell T, Gold L, Biro MA, et al. Effects of continuity of care by a primary midwife (caseload midwifery) on caesarean section rates in women of low obstetric risk: The COSMOS randomised controlled trial. BJOG An Int J Obstet Gynaecol. 2012;119(12):1483-92.

5. Forster DA, McLachlan HL, Davey MA, Biro MA, Farrell T, Gold L, et al. Continuity of care by a primary midwife (caseload midwifery) increases women's satisfaction with antenatal, intrapartum and postpartum care: Results from the COSMOS randomised controlled trial. BMC Pregnancy Childbirth [Internet]. 2016;16(1):1-13. Available from: 
http://dx.doi.org/10.1186/s12884016-0798-y

6. Andriani L. Hubungan Tingkat Pengetahuan Dengan Kinerja Bidan Dalam Pengisian Kartu Skor Poedji Rohyati Pada Deteksi Dini Kehamilan Risiko Tinggi di Puskesmas Kabupaten Lima Puluh Kota. J Menara Med [Internet]. 2019;2(No.1):56-60. Available from: https://jurnal.umsb.ac.id/index.php/m enaramedika/index

7. Pangastuti N. Robekan Perinium Pada Persalinan Vaginal di Bidan Praktek Swasta (BPS) Daerah Istimewa Yogyakarta Indonesia Tahun 20142016. J Kesehat Reproduksi. 2016;3(3):179-87.

8. Oktaviani I, Makalew L, Solang S. Profil Haemoglobin Pada Ibu Hamil Dilihat Dari Beberapa Faktor Pendukung. J Ilm Bidan. 2016;4(1):22-30.

9. Djunizar Djamaludin LN. Pengaruh Pemberian Nafas Dalam Terhadap Nyeri Persalinan Kala I di BPJS HJ Riza Faulina, S.ST Wilayah Kerja Puskesmas Raja Basa Indah Kota Bandar Lampung. J Kesehat Holistik (The J Holist Heal. 2016;10(3):1-4.

10. Riyanto. Faktor Risiko Kejadian Retensio Plasenta Pada Ibu. J Kesehat Metro Sai Wawai. 2015;VIII(1):3844.

11. Nurhayati E. Indeks Massa Tubuh (IMT) Pra Hamil dan Kenaikan Berat Badan Ibu Selama Hamil Berhubungan dengan Berat Badan Bayi Lahir. J Ners dan Kebidanan. 2016;4(1):1-5.

12. Manuaba IG. Ilmu Kebidanan Penyakit Kandungan Dan Keluarga
Berencana. Setiawan Sk, editor. Jakarta: EGC; 1998.

13. Bingan ECS. Pemakaian KB Suntik 3 Bulan dengan Kecukupan ASI Eksklusif pada Ibu yang Mempunyai Anak Usia 7-23 Bulan. J Ilm Bidan [Internet]. 2019;6(2):65-71. Available from: https://ejurnal.poltekkesmanado.ac.id/index.php/jidan/article/ view/819 